\title{
Humor and Reading Motivation in Children: Does the Tickling Work?
}

\author{
Olufolake Sophia Orekoya, ${ }^{1, *}$, Edmund SS Chan $^{1} \&$ Maria PY Chik ${ }^{1}$ \\ ${ }^{1}$ Department of Education Studies, Hong Kong Baptist University, Kowloon Tong, Hong \\ Kong \\ *Corresponding author: Tel: 852-5535-9520Ｅ-mail: rockhaven50@gmail.com
}

Received: December 10, 2013 Accepted: December 30, 2013 Published: February 22, 2014

doi:10.5296/ije.v6i1.4724 URL: http://dx.doi.org/10.5296/ije.v6i1.4724

\begin{abstract}
In spite of employing various reading techniques by teachers to motivate their students, some techniques may be less effective as they tend to repress rather than to motivate reading in children. Educators to some extent could unintentionally deter as opposed to allay the fears of reluctant young readers, consequently hampering the development of their intrinsic motivation for reading. This article sheds light into children's appreciation of humour and its effect on their reading abilities; children's reading preferences, and how to motivate them. The benefits and significance of humour socially, and cognitively through the facilitation of playful learning environment, reduction of learning anxiety, and the stimulation of students' learning motivation, are liable of creating in children the desire for the tickling sensation that accompanies humourous reading materials. An appraisal of global trend of children's strong preference for funny, riddles and joke books, in conjunction with an overview of the sense of humour, its appreciation and the use of humour as an adaptive mechanism in young readers, are among the noteworthy insights presented for educators to ruminate upon.
\end{abstract}

Keywords: humor; intrinsic; reading; motivation; children 


\section{Introduction}

Humor as simple as it seems has greatly puzzled early philosophers and later psychologist, as it assumes the complexity of the human phenomenon for the intricacy of analysis (Ziv, 1976). Apart from its therapeutic function, humor is identified to play an important role in human cognitive, social, emotional and moral development (Martin, 2007). A few research projects on the influence of humor in the educational experience of humor and learning are based on convergent thinking. Humor studied in relation to creativity revealed that highly creative children have better sense of humor than their peers and a similar correlation was found in another study with undergraduate students (Ziv, Shulman, \& Schleifer, 1979).

Freud in his attempt to relate play, daydreaming and humor to act on creativity, according to Ziv (1989), paved the way for contemporary research on humor. Although Freud's writing was based on adults' experience whereby he divided creativity into: process and product, the aspect of children creativity involves the cognitive process solely in the creative act. Based on Gilford, (1959) the theory on the structure of intellect proposed the two types of thinking; convergent and divergent. The divergent thinking is noted to be related to creativity, producing a variety of results or responses. This is opposed to convergent which is related to intelligence. However, creativity testing is confined to the cognitive aspect; not having bearing on the behavioral product (Ziv, 1989). Children are noted to be easily adaptable to the bond in humor and creativity which is addressed as cognitive playfulness.

\section{Issues affecting reading motivation}

Teachers are great in their quest in using various reading techniques to motivate their students. However, some techniques are just as less effective as they tend to repress rather than motivate reading. The idea of intrinsic reading motivation is embedded in young reader's choice of reading materials. Mohr, (2006) urged educators to understand children's reading preferences, and how to motivate them. The need for children's choice in reading motivation is emphasized by Jones, Hartman, and Taylor (2006), "the most important aspect of teaching the reluctant reader is to remove his fear” (p. 35). In order to effectively facilitate children's reading development, one should understand their book preference and reading habit.

A two -year investigation into learning and teaching of children's literature in Europe by the university of West England, university of Akureyri in Iceland, Gazi university in Turkey and the university of Marcis in Spain under the sponsorship of the European commission for lifelong learning program, among the elementary students revealed that most children do like to read books that make them laugh with : 69\%, 65\%, 57\% and 53\% in agreement amongst children from Spain, UK, Iceland and Turkey respectively (Adalsteinsdottir, 2011). Results of information gathered on what makes students active readers showed that children like ecstasy and funny (humorous) story books. "Children often say that they like books that make them laugh or books they find are exciting to read and the least popular reason for liking a book seems to be that it makes children sad" (Adalsteinsdottir p. 43). The study reported children's reading preferences ranging from funny stories, adventurous stories, fantasy and others. Most 
children opined that they would reread the books that they like the story. $59 \%$ of the Pupils agreed they would read longer when they choose their own books and subjects that interest them. In the UK, $31 \%$ of the children reported they have never borrowed books in the library. Children generally like to read at their own time and disclosure, as the results showed that $82 \%$ of the children respondents preferred to read in their bedroom.

A recent report of the Progress in International Reading Literary Study by Mullis, Martin, Foy, and Drucker (2011) indicated that Hong Kong is lagging behind on students motivated to read (Hong Kong: 52\% of students; International average: $74 \%$ of students) and confident in reading (Hong Kong: 20\% of students; International average: 36\% of students). From 2005 to 2013, 20 reading enhancement programs for primary school children were funded by the government (http://qcrc.qef.org.hk) with emphasis on the development of reading strategies and language proficiency. From the foregoing, two major limitations are noteworthy: first, educators need to address the reasons for unmotivated readers. Second, a large number of books selected do not match students' literary level consequently; students may waste time awaiting the availability of their desired books in the library.

Based on the data of "The Progress in International Reading Literacy Study (PIRLS, 2001)”, a comparative study was conducted by Tse et.al., (2006) comparing the reading attainment among children in Hong Kong, Singapore and England. Findings revealed that Singaporean students scored highest in reading attitude and reading confidence. The poor performance of Hong Kong students was aligned to examination-oriented learning atmosphere and other socio-political reasons. A further explanation of the differences between the two groups might be related to students 'reading habit'; depicting that Hong Kong students read less frequently than and somewhat differently from their Singaporean counterparts. According to Majid and Tan (2007), Singaporean primary students' most important reason of leisure reading was academic achievement. Other reasons included acquiring knowledge, relaxation, and habitual activity. $47.3 \%$ of the participants reported leisure reading daily, $13.9 \%$ every other day, and $19.6 \%$ during weekends. The study showed comedy series was the third most popular reading material. Storybooks ranked the highest preference of reading materials, followed by comics, magazines, internet/websites, information non-fiction books, and newspaper.

Firth (2011), proposed five ways of motivating boys to read which to include non-fiction, humour, graphic novels, comic books, wordless books, fantasy and science fiction. Shannon Firth (2011) the author of 'five ways to get boys to read' asserted that in the United States among elementary students, 72 percent of boys are considered "proficient” readers, compared to 79 percent of girls. Addressing the need for more effort in motivating boys to read, the author agreed with a body of literature that centers on the concept of a "good book" which tends to include books that are emotional rather than physical, adding that books with gross humor or scary stories are amongst the most appealing to boys. On a different note, Mohr (2006) in a three-part investigation into first graders' preferences, selection rationales, and processes when choosing a picture book to own, discovered that most of the children selected informational books, especially animal books, a reaction which is viewed as a contradiction to the popular notion that children especially girls would prefer narratives. 


\section{Research methodology on humor}

Psychologists developed various measurement tools to unveil the nature of humor; one of which was to associate personality trait of interest with types of humor (Ruch, 1998). Ruch used the approach of measuring sense of humor as a multi-dimensional construct. Researchers employed self-report instruments to investigate correlations among humor styles and other variables (e.g. Humor Styles Questionnaire (HSQ), Martin, Puhlik-Doris, Larsen, Gray, \& Weir, 2003; Erickson \& Feldstein, 2007). A body of literature confirms that researchers constructed different scales for measuring numbers of dimensions of sense of humor in both adult and children (Ho, Chik, \& Chan, 2011). Among the dimensions of humor is the Thorson and Powell (1993)'s 24-item Multidimensional Sense of Humor Scale, (MSHS) a measurement tool which was widely used cross-culturally. Others include the Australian (Boyle \& Joss-Reid, 2004), Croatia (Thorson, Brdar, \& Powell, 1997), Portugal (Jose, Parreira, Thorson, \& Allwardt, 2007) and Hong Kong (Ho, Chik, \& Thorson, 2008). Using factor analysis, Thorson and Powell (1993) proposed that personal sense of humor is made up of six elements that include: humor production; a sense of playfulness or whimsy; the ability to use humor to achieve social goals; personal recognition of humor; appreciation of humor; and the use of humor as an adaptive mechanism. Dowling, Hockenberry, and Gregory (2003) modified MSHS to measure children's sense of humor (Multidimensional Sense of Humor Scale for Children, MSHSC) and identified three factors: humor creation, coping with humor, and humor appreciation. Ho, Chik and Chan (2011) validated the Chinese version of the MSHSC (C-MSHSC) through exploratory and confirmatory factor analyses and validity tests, and the authors' study supported these three theoretical humor dimensions for children.

\section{Humor appreciation in children}

Personal sense of humor as proposed by Thorson and Powell (1993) using factor analysis is made up of six elements such as: humour production, a sense of playfulness or whimsy, the ability to use humour to achieve social goals, personal recognition of humour, appreciation of humour, and the use of humor as an adaptive mechanism. Dowling, Hockenberry, and Gregory (2003) modified MSHS to measure children's sense of humour (Multidimensional Sense of Humor Scale for Children, MSHSC) identifying three factors: humour creation, coping with humour, and humor appreciation. Ho, Chik and Chan (2012) validated the Chinese version of the MSHSC (C-MSHSC) through exploratory and confirmatory factor analyses and validity tests. Among the dimensions of sense of humour, humour appreciation being an early research topic in the field of humor studies happens to be relatively important to child development. In fact, the first assessment tools of sense of humour focused on the appreciation of verbal and pictorial humour (Carretero-Dios, Pérez, \& Buela-Casal, 2009; 2010). Humour appreciation could be understood as "the experience of finding something amusing” (Kaufman, Kozelt, Bromley, \& Miller, 2008, p. 241). Drawing from the works of McGhee, Shultz, Selman and other relevant literature, Lamert (1989) outlined the developmental changes on incongruity perception in early childhood. An infant as young as three months old could recognize something unfamiliar and unfit to its schema. With growth 
of memory capacity and learned "Object Permanence”, an eight-month infant laughed at strange visual stimuli and such early laughter implied that humor comprehension might possibly occur.

About 18 months of age, a toddler shows the sign of humour production as she generates incongruous action towards an object during playful exploration. As a child's language ability develops, he or she learns to mislabel or even incongruously categorizes objects and events (i.e., they might equate cats with dogs (Lamert, 1989). A child at three to seven years of age can display imagination of conceptually incongruous objects (i.e., a bicycle with squared wheels) and start to appreciate jokes and riddles thereby, reflecting conceptual and linguistic incongruities; double meanings of a word. At seven years of age, logical incongruity emerges as a child gradually acquires the concept of conservation and class inclusion. From seven years of age to adolescence, a child learns to understand other person's perspectives (i.e. expectations, feelings and social judgment) and such understanding being prerequisite of appreciation of ironic incongruity (Lamert, 1989). As a child becomes more mature cognitively, one could imply that he or she is liable to appreciate different forms of humour.

Apparently, humour appreciation is closely related to cognitive development. "Finding something amusing" indeed is a complicated process involving stimuli, responses and persons. Thus, Ruch and Franz-Josef (1998) proposed a two-mode model for humour appreciation which included three factors of humor stimuli and two components of responses: incongruity-resolution humour, nonsense humour, and sexual humour respectively. The response mode of humour appreciation refers to funniness (positive response of the stimuli) and evasiveness (negative response of the stimuli). Derks, Staley, and Haselton (1998) found that incongruity-resolution humour best predicted amusement (funniness of the cartoon in the study) with sample of university students. This finding was further supported by experimental studies of Chik, Leung, and Molloy (2005a, 2005b) with sample of Hong Kong primary school children who rated incongruous pictures significantly funnier than congruous pictures. Therefore, the authors confirmed that incongruity was an indispensable component of humour appreciation universally. When a child is engaged in humour appreciation, he or she intends to finish a problem-solving exercise to identify and unfold the incongruity hidden beneath the humour stimuli (Zigler, Levine, \& Gould, 1967).

Six types of incongruity enjoyed by children are: physical discrepancy, distortion/ exaggeration, violation of expectations, violation of rational behavior, violation of conceptual thought, and language rule (Klein, 2003). Although cognitive factors seemed to contribute significantly to humour appreciation, this finding was not conclusive. Humor production and appreciation are positively related to social competence and academic achievement because humor is positively related to intellectual abilities (Masten 1986). However, no functional relationship between humour and academic achievement was found. Three years later, Masten (1989) found that children with higher intellectual abilities and socioeconomic status displayed more mirth. Moreover, children who were more advanced intellectually and had possessed higher comprehension skill level were able to appreciate more difficult cartoons.

However, Prentice and Fathman (1975) showed that comprehension was not related to 
enjoyment of jokes and riddles although cognitive ability (as indicated by school grades: Grade 1, 3 and 5) was positively related to comprehension of jokes and riddles. Such discrepancy might be due to emotional or other factors. Derks et al. (1998) indicated that comprehension-difficulty did not predict amusement and environmental factor was related to evasiveness (negative response to humorous stimuli). A body of literature supports the idea that humor development in children can be related to social, cognitive, and linguistic development (Semrud-Clikeman \& Glass, 2008). The authors examined humour comprehension in children comparing children with nonverbal (NVLD) learning disabilities and a comparison group of children with no learning disabilities. The children' understanding of humour were measured by the use of humour testing verbal joke section and a cartoon with a captions section. 55 participants within the age range of 12-15 years were tested. Results indicated there were no group differences found in humour comprehension. The results of the ANCOVA with FSIQ as a covariate which showed no significant differences numerical between group means were opposed to the assumption that the NVLD group would have a higher error rate than the RD group or the comparison group. Social perception (rather than intellectual level) according to Semrud-Clikeman and Glass (2008) was discovered to be associated with humour comprehension of children with non-verbal learning disabilities (NVLD).

Children with intellectual disabilities had greater appreciation with physical and visual humor; funny action, changes in size and color than with verbal humor such as funny jokes and comments (Degabriele \& Walsh, 2010). This preference was due to less cognitive challenge of perceiving the physical/ visual humour and the more familiar presentations of humorous stimuli (i.e. video cartoon pictures).Comparing Chinese and Greek preschoolers' humor recognition, Guo, Zhang, Wang, and Xeromeritou (2011)'s experimental study indicated that humour response level of Chinese children was negatively correlated to their intellectual level although their frequency of humour recognition is positively related to their cognitive development. Particularly, Chinese children with higher intellectual level displayed fewer laughers because they possessed higher social-cognition as well. It was possible that laughing openly in front of teachers was regarded by the Chinese participants as inappropriate so that they controlled their expressions. Thus, these researchers concluded that cultural factor played a role in humor appreciation.

\section{Humor and reading motivation for children}

Literature confirms the benefits and significance of humour for school learning socially, cognitively, affectively and behaviorally since it facilitates playful learning environment, lessened learning anxiety, stimulated students' learning motivation, and deepened teacher-student relationship (Davies \& Apter, 1980). Humour literature has for sometime been regarded as interesting and attractive among young children (Higginbotham, 1999; Struthers, 2003). In fact, humour is the genre consisting of comic narratives, such as pun, joke and irony (Ermida, 2008).

When children read humourous texts, they engaged in a "cognitive play", "where words and 
concepts are used in ways that are surprising, unusual, and incongruous, activating schemas with which they are not normally associated” (Martin, 2007, p. 109; Shultz \& Robillard, 1980). Such cognitive activity possibly activated positive emotion of mirth (i.e. enjoyment), leading to enhancement of creativity, memory and social virtues that include: sense of responsibility, helpfulness and generosity) (Martin, 2007).

Chik (2005) found that the Humourous English Reading Program evidently moderated the decline of reading motivation with respect to increase of age. Humorous materials on students reading motivation-analysis T test and repeated measure of ANOVA by Chik (2005) showed significant changes in students' intrinsic and extrinsic motivation reading with the primary six students exhibiting stronger intrinsic motivation. In particular, the intrinsic motivation of the primary six students was significantly increased despite significant decrease of extrinsic motivation. Lee-Daniels \& Murray (2000) both teachers, reported using the book worm posting to motivate their students for independent reading. The book worm is a form of a classroom display of students' intrinsic independent reading time by the display of the number of pages read. The fun part of having the children' s bookworm reading graph moved that is; wiggled around the board in increments of certain number of pages read, caught students' attention thereby stimulating their interest in reading.

In another related study, Zipke (2008) used riddles to teach metalinguistic awareness of reading comprehension with 46 third grade students who were tested after being exposed to lessons using riddles to identify and define homonyms and reading and writing stories that are in conjunction with the original of Peggy Parish's 'Amelia Bedelia' series. Results showed that the students exposed to riddles teaching approach scored higher on both the pretest and posttest than the control students. The author identified the fun aspect of using riddles in reading and writing as part of the reason for the enthusiasm and motivation shown by the students. "Riddles offer especially engaging instructional content for teaching language manipulation for many reasons: Most children are familiar and comfortable with riddles” (p.131).

Humorous poetry can be an excellent approach to motivation. The combination of humourous and repeated reading approaches, with modeling, had been observed to have significant movement and automatic word recognition and fluency (Wilfong, 2006). Dee Anderson (2009) the American author of "Reading is Funny" opines that the intention to "tickle" children's funny bones, is one of the reasons why riddles help in reading motivation for children. Anderson believes laughter brightens and keeps people energized including the young ones. The author maintains that, "a sense of humour makes life more bearable” (p.1). Other reasons for which to share riddles with children include sensation of tickling their brains.

Anderson (2009) referring to the Swiss psychologist Jean Piaget that children between the ages of six and seven do possess "concrete operational thinking”. Anderson, through observation and experience in children reading motivation views riddles as capable of helping children to understand diverse meaning of words, to increase background knowledge, and the enhancement of critical thinking. The author reinstates that riddles help children enlarge their 
vocabulary list with ease, and motivates children's interest in reading through increase curiosity.

The act of mastery that riddles give to children can boost their confidence as they are elated to see that they can actually use their new found weapon of riddles to fool others even grownups. The advantages of employing jokes as fluency texts surpass the idea that jokes enable readers to have fun with reading; jokes are avenues for learning new vocabulary, and diverse facets of meanings of words (Ness, 2009). Reading fluency, an idea supported by the 2000 report of the National Reading panel of the National Institute of Child Health and Human Development, is viewed as vital in the recognition of reading ability in general, to children.

Ness (2009) identified prosody - a multifaceted application of emphasis, stress, intonation and punctuation with careful attention to the tempo and rhythm of the text in reading, to be one of the most important factors that determine fluency in reading. Most readers who struggle with prosody are hampered in their reading skills; as they can be less confident in reading.-especially reading aloud Ness, (2009). The author described a one -on-one tutoring experience with a struggling influent student who was able to enthusiastically use a joke book to focus on the salient rudiments of prosody with much ease and became a fluent reader through the use of 'funny' joke books.

\section{Conclusion}

When children are motivated to read, they tend to seek to understand, enjoy learning, and have confidence in their reading abilities. Hence children develop the intrinsic value of reading which enables them to read with enthusiasm, curiosity and critically thinking through the challenges of the pages before them. If educators are to raise intrinsic and motivate readers, it is time to evaluate the importance of scheme books versus 'real book' (books that meet children's needs). It is observed that the latter encourages and motivates reading the better. Therefore, it is pertinent to emphasize the need to implement the perceived reading needs of students based on empirical findings such as the need to help students to be proactive readers. Reading aloud to kids is a great tool but more importantly is the need to know what children expect when teachers read aloud to them. Adalsteinsdottir, (2011) in the study on teaching literature in Europe, asked why children think their teachers read out loud to them, they replied that it is in order that they can enjoy the story second only to learning new ideas and vocabulary from such story. Children would like to share and talk about the story being read out loud by being actively involved to acquire new vocabulary but also, to be independent intrinsic readers. 


\section{References}

Adalsteins dottir K. (2011). Learning and Teaching Children's Literature in Europe Retrieved August 5, 2013 from http://www.um.es/childrensliterature/site/file.php/1/Deliverables/LTCL_final_Report.pd $\mathrm{f}$

Anderson, D. (2009). Reading Is Funny!: Motivating Kids to Read with Riddles. Retrieved August 8, 2013 from http://books.google.com.hk/books/about/Reading_Is_Funny.html?id=

Boyle, G. J., \& Joss-Reid, J. M. (2004). Relationship of humor to health: A psychometric investigation. British Journal of Health Psychology, 9, 51-66.

Carretero-Dios, H., Pérez, C., \& Buela-Casal, G. (2009). Content validity and metric properties of a pool of items developed to assess humor appreciation. The Spanish Journal of Psychology, 12(2), 773-87

Carretero-Dios, H., Pérez, C., \& Buela-Casal, G. (2010). Assessing the appreciation of the content and structure of humor: Construction of a new scale Humor: International Journal of Humor Research, 23(3), 307-325. http://dx.doi.org/10.1515/HUMR.2010.014

Chik, M. P. Y. (2005). Humor and reading motivation in Hong Kong elementary School Children (Electronic version: http://ierg.net/ierg2005/papers/081-Chik.pdf) Proceedings: International Conference on Imagination \& Education, 13-16 July, Simon Fraser University, Canada.

Chik, M. P. Y., Leung, C. S. B., \& Molloy, G. N. (2005a). Development of a measure of humor appreciation Australian Journal of Educational \& Developmental Psychology, 5, 26-31.

Chik, M. P. Y., Molloy, G. N., \& Leung, C. S. B. (2005b). Incongruity as a universal component of humor appreciation: Some Hong Kong data. Australian Journal of Educational \& Developmental Psychology, 5, 40-54.

Davies, A. P., \& Apter, M. J. (1980).Humor and its effects on learning in children In P. E. McGhee, \& A. J. Chapman (Eds.), Children's humor (pp.237-253). Chichester England: John Wiley \& Son.

Degabriele, J., \& Walsh, I. P. (2010). Humor appreciation and comprehension in children with intellectual disability. Journal of Intellectual Disability Research, 54(6), 525-537. http://dx.doi.org/10.1111/j.1365-2788.2010.01277.x

Derks, Staley, R. E., \& Haselton, M. G. (1998). "Sense” of humor: Perception, intelligence, or expertise? In W. Ruch (Ed.), The Sense of Humor: Explorations of a personality characteristics (pp. 143-158). New York: Mouton de Gruyter.

Dowling J. S., Hockenberry, M., \& Gregory, R. L. (2003). Sense of humor, childhood cancer stressors, and outcomes of psychosocial adjustment, immune function, and infection. 
Journal of Pediatric Oncology Nursing, 20, 271-292. http://dx.doi.org/10.1177/1043454203254046

Erickson, S. J., \& Feldstein, S. W. (2007). Adolescent humor and its relationship to coping, defense strategies, psychological distress, and well-being Child Psychiatry and Human Development, 37(3), 255-271. http://dx.doi.org/10.1007/s10578-006-0034-5

Ermida, I. (2003). The language of comic narratives: Humor construction in short stories. New York: Mouton de Gruyter.

Firth, S. (2011). 5 Ways to Get Boys to Read. Retrieved August 5, 2013 from http://www.findingdulcinea.com/news/education/2010/april/5-Ways-to-Get-Boys-to-Rea d.html

Gilford, J. P. (1959). Three faces of intellect. American Psychologist, 14(8), 469-479. http://dx.doi.org/10.1037/h0046827

Guo, J., Zhang, X., Wang, Y., \& Xeromeritou, A. (2011). Humour among Chinese and Greek preschool children in relation to cognitive development. International Electronic Journal of Elementary Education, 3(3), 153-170.

Higginbotham, S. (1999). Reading interests of middle school students and reading preferences by gender of middle school students in a Southeastern State. Master's Thesis Dissertations, Mercer University, ED 429279. Retrieved August 13, 2013 from files.eric.ed.gov/fulltext/ED429279.pdf

Ho, S. K., Chik, M. P. Y., \& Thorson, J. A. (2008). Psychometric study of a Chinese version of the multidimensional sense of humor scale North American Journal of Psychology, $10,425-434$.

Ho, S. K., Chik, M. P. Y., \& Chan, D. W. K. (2012). A psychometric evaluation on the Chinese version of the multidimensional sense of humor scale for children (C-MSHSC). Child Indicators Research, 5, 77-91. http://dx.doi.org/10.1007/s12187-011-9114-6

Jones, P., Hartman, M. L., \& Taylor, P. (2006). Connecting with reluctant teen readers: Tips, titles, and tools. New York: Neal-Schuman Publishers.

José, H., Parreira, P., Thorson, J. A., \& Allwardt, D. (2007). Multidimensional aspects of the sense of humor: A psychometric study of the MSHS on the Portuguese population, North American Journal of Psychology, 9, 595-610.

Kaufman, S. B, Kozelt, A., Bromley, M. L, \& Miller, G. L. (2008). Creativity and humor in human mate selection (pp. 227-262) In G. Geher \& G. Miller (Eds.), Mating intelligence: Sex, relationships, and the mind's reproductive system. New York: Lawrence Erlbaum Associates.

Klein, A. J. (2003). Introduction: A global perspective of humor. In A. J. Klein (Ed.), Humor in children's lives: A guidebook for practitioners (pp. 3-15). Westport, CT: Praeger.

Lamert, M. D. (1989). The appreciation and comprehension of ironic humor from nine to 
eighteen Retrieved from ProQuest Digital Dissertations. (UMI 9006405) Retrieved August 14, 2013 from http://pqdt.calis.edu.cn/SearchResults.aspx?pm=1\&q=paper:\%289006405\%29

Lee-Daniels, S. L., \& Murray, B. A. (2000). DEAR Me: What Does It Take to Get Children Reading? The Reading Teacher, 54(2), 154-155.

Majid, S., \& Tan, V. (2007). Profiling the reading habits of children in Singapore. International Association of School Librarianship Selected Papers from the Annual Conference, 1-12. Retrieved from http://search.proquest.com/docview/236086725?accountid=11440

Martin, R. (2007). The psychology of humor: The integrative approach. New York: Elsevier.

Martin, R., Puhlik-Doris, P., Larsen, G., Gray, J., \& Weir, K. (2003). Individual differences in uses of humor and their relation to psychological well-being: Development of the Humor Styles Questionnaire. Journal of Personality, 37(1), 48-75. http://dx.doi.org/10.1016/S0092-6566(02)00534-2

Masten, A. S. (1986). Humor of competence in school-aged children. Child Development, 57, 461-473.

Masten, A. S. (1989). Humor appreciation in children: Individual differences and response set International Journal of Humor Research, 2(4), 365-384.

Mohr, K. A. J. (2006). Children's Choices for Recreational Reading: A Three-Part Investigation of Journal of Literacy Research, 38(1), 81-104.

Mullis, I.V.S., Martin, M.O., Foy, P., \& Drucker, K.T. (2012). PIRLS,2011 International results in reading Chestnut Hill, MA:TIMSS \& PIRLS International Study Center. Retrieved August 15, 2013 from http://timssandpirls.bc.edu/pirls2011/international-results-pirls.htmlcite

Ness, M. (2009). Laughing through Readings: Using Joke books to Build Fluency. The Reading Teacher, 62(8), 691-694.

Prentice, N. M., \& Fathman, R. E. (1975). Joking riddles: A developmental index of children’s humor. Developmental Psychology, 11(2), 210-216.

Ruch, W., \& Franz-Josef, H. (1998). A two-mode model of humor: Its relation to aesthetic appreciation and simplicity- complexity of personality. In W. Ruch (Ed.), The Sense of Humor: Explorations of a personality characteristics (pp. 109-142). New York: Mouton de Gruyter.

Ruch, W. (1998). Sense of humor: A new look on the old concept. In W. Ruch (Ed.), The sense of humor: Explorations of a personality characteristics (pp. 3-14). New York: Mouton de Gruyter.

Semrud-Clikeman, M., \& Glass, K. (2008). Comprehension of humor in children with nonverbal learning disabilities, reading disabilities, and without learning disabilities 
Annals of Dyslexia, 58(2), 163-80.

Shultz, T. R., \& Robillard, J. (1980). The development of linguistic humor in children: Incongruity through rule violation. In P. E. McGhee, \& A. J. Chapman (Eds.), Children's humor (pp. 59-90). Chichester: John Wiley \& Son.

Struthers, A. (2003). No laughing! Playing with humor in classroom In A. J. Klein (Ed.), Humor in children's lives: A guidebook for practitioners (pp. 85-94). Westport, CT: Praeger.

Thorson, J. A., \& Brdar, I., \& Powell, F. C. (1997). Factor-analytic study of sense of humor in Croatia and the USA. Psychological Report, 81, 971-977.

Thorson, J. A., \& Powell, F. C. (1993). Development and validation of a multidimensional sense of humor scale. Journal of Clinical Psychology, 49, 13-23.

Zigler, E., Levine, J., \& Gould, L. (1967). Cognitive challenge as a factor in children in children's humor appreciation Journal of Personality and Social Psychology, 6(3), 332-336. http://dx.doi.org/10.1037/h0024729

Zipke, M. (2008). Teaching Metalinguistic Awareness and reading Comprehension with Riddles. The Reading Teacher, 62(2), 128-137.

Ziv, A. (1976). Facilitating effects of humor on creativity. Journal of Educational Psychology, 68(3), 318-322. http://dx.doi.org/10.1037/0022-0663.68.3.318

Ziv, A. (1989). Using humor to develop creative thinking. In P. E. McGhee (ed.). Humor and children's development (pp. 99-115) New York: Haworth Press.

Ziv, A., Shulman, S., \& Schleifer, H. (1979). Moral development: Parental and peer group influence on Kibbutz and city children. Journal of Genetic Psychology, 134, 233-240.

\section{Copyright Disclaimer}

Copyright reserved by the author(s).

This article is an open-access article distributed under the terms and conditions of the Creative Commons Attribution license (http://creativecommons.org/licenses/by/3.0/). 